\title{
Innovation and productivity in formal and informal firms in Ghana
}

\section{Article}

Accepted Version

Creative Commons: Attribution-Noncommercial-No Derivative Works 4.0

Fu, X., Mohnen, P. and Zanello, G. (2018) Innovation and productivity in formal and informal firms in Ghana.

Technological Forecasting \& Social Change, 131. pp. 315-325. ISSN 0040-1625 doi:

https://doi.org/10.1016/j.techfore.2017.08.009 Available at https://centaur.reading.ac.uk/72033/

It is advisable to refer to the publisher's version if you intend to cite from the work. See Guidance on citing.

To link to this article DOI: http://dx.doi.org/10.1016/j.techfore.2017.08.009

Publisher: Elsevier

All outputs in CentAUR are protected by Intellectual Property Rights law, including copyright law. Copyright and IPR is retained by the creators or other copyright holders. Terms and conditions for use of this material are defined in the End User Agreement.

\section{www.reading.ac.uk/centaur}

\section{CentAUR}

Central Archive at the University of Reading 
Reading's research outputs online 


\title{
Innovation and productivity in formal and informal firms in Ghana
}

Xiaolan Fu, Pierre Mohnen, and Giacomo Zanello*

\begin{abstract}
Despite the high profile of the issue in current policy formulations in lowincome countries (LICs), there is little large firm level survey based empirical evidence on innovativeness and firm performance, especially in informal establishments. This paper aims to fill this gap in the literature using a revised Crépon-Duguet-Mairesse (CDM) structural model to analyse data from a unique innovation survey of 501 manufacturing firms in Ghana. We find that innovation positively impacts the labour productivity of firms, technological innovations more than managerial innovations. Formal firms do not tend to be more productive than informal firms, but the role of innovation on productivity tends to be greater for formal firms.
\end{abstract}

Keywords: Innovation, productivity, informality, Ghana. 


\section{Introduction}

The economic growth of low-income countries (LICs) is a product of ideas, skills, capital, and the organization of society and firms (Fagerberg et al., 2010). It has not been different in the economic history of currently developed countries, where main industrial revolutions were all linked to an application and spread of an innovation - steam power, electricity, and informatics - resulting in a remarkable increase in total factor productivity, societal changes, and ultimately improvement in the wealth and welfare of nations. The past also shows that the real impact of technologies and advancement in knowledge occurs when they are diffused and adopted by a large range of actors, within a country and in other countries as well. Yet, hosting countries not only have to face financial constraints to acquire the technology, but also to develop an absorptive capacity (knowledge and skills) able to adopt and possibly reproduce such technologies (Cohen and Levinthal, 1989). The steam engine is a demonstrative example: it was invented in the United Kingdom at the end of the $18^{\text {th }}$ century, but its diffusion to other countries took decades. Even if the Chinese empire came across this technology during the First Opium War (1839-1842), its potential impact was not fully realized at first, and then it took two decades to overcome the knowledge and skills gaps (mainly in term of technical drawing and machine tools) for the Chinese to adopt and produce steam engines (Wang, 2010). The first steam engine built in China was manufactured in 1869, almost hundred years after its invention in the United Kingdom. At that time, the second industrial revolution was in its infancy in Europe, and the streets of European capitals were soon starting to have electric lighting.

In the macroeconomic literature, it is widely recognised that innovation is a major driver of economic growth (Grossman and Helpman, 1991). As extensively documented in Fagerberg et al. (2010), two factors have been identified as critical factors in the endogenous economic growth models: adoption of technologies developed elsewhere and indigenous innovative capacity. However, the technology diffusion to, and adoption by, developing countries is costly and conditional on factors that support the process (Keller, 2004). It relies on substantial and well-directed technological efforts (Lall, 1992) as well as sufficient human and financial resources and absorptive capacity (Cohen and Levinthal, 1989; Keller, 1996). As highlighted in Fu and Gong (2011), it also requires appropriate institutions and policies to guide incentives and facilitate the process, in addition to strong local capabilities to identify the right technology and appropriate transfer mechanism according to local economic, social, technical and environmental conditions. Trade (import and export) and foreign direct investments can become important sources of growth for catching-up countries.

The macro-level evidence is supported by empirical studies that strongly suggest that the level of technological innovation contributes significantly to economic performance, particularly at the firm and industry level (see for example Kleinknecht and Mohnen, 2002). Firms' growth is seen as a learning process in which firms that are able to adopt and create 
technologies and knowledge grow and survive, while firms that do not innovate decline and fail (Jovanovic, 1982). This is particularly relevant in the context of LICs in which the learning process is the major factor enabling innovation activities in firms (Bell and Pavitt, 1992; Lall, 1992). Low-income countries face severe constraints and, as argued by Lundvall et al. (2010), technological capabilities in these countries encompass more than just research and development (R\&D). In such environments, learning-based innovations - such as adoption or adaptation of both technological and no-technological innovations - are significant factors for the industrial development.

The richness of the data on innovation in emerging and developed countries has allowed researchers to implement an econometric approach, such as the widely used Crépon-DuguetMairesse (CDM) structural model (Crepon et al., 1998), in which firm performance is a function of product and/or process innovation, which in turn are explained by R\&D and other innovation expenditures. In the context of developing countries, the lack of data at longitudinal level and the fact that for the vast majority of firms R\&D activities are only a marginal determinant in innovation activities have posed several challenges in modelling innovation and growth. Nonetheless, in recent years an increasing number of empirical studies have analysed the role of innovation in LIC firms, both exploring its determinants (Goedhuys, 2007; Robson et al., 2009) and the impact it has on various firm performance indicators (Gebreeyesus, 2009; Goedhuys et al., 2008, 2014). Most of the latter studies focus on product and process innovations and their impact on productivity. However, as argued by various scholars (Bloom et al., 2013; Bruhn et al., 2010; Crespi and Zuniga, 2012; Mano et al., 2012) in the current state of development of LICs it is important to recognize the impact of a range of innovations, including management and marketing innovations, the impact of which could go further than an improvement in productivity.

In analysing the contribution of innovation to firm performance, it is important to recognize that in most of the developing countries a dual-economy system exists with formally registered firms and an informal sector. In a recent survey on informality and development, La Porta and Shleifer (2014) provide five stylized facts of the informal economy in developing countries. The informal sector employs a large proportion of workers and tends to escape taxation and controls from the authorities. Moreover, it is characterized by small and inefficient firms, which are ran by poorly educated entrepreneurs, and as a consequence its productivity is very low. Capturing the magnitude and impact of the informal sector is problematic because of its intrinsic nature, but it has been estimated that the weighted average size of the shadow economy (as a percentage of GDP in the period 1999-2007) in Sub-Saharan Africa is around 40 per cent (Schneider et al., 2011) and makes up to 80 per cent of non-agricultural employment (Chen et al., 1999). As shown in Wunsch-Vincent and Kraemer-Mbula (2016), the different capabilities of firms in the formal and informal sectors are likely to shape the innovation adoption and diffusion. For example, formal establishments may have the human and capital resources to collaborate in innovation activities with other 
firms, research and development institutions, or, for larger firms, with foreign institutions (Oyelaran-Oyeyinka et al., 1996). Informal firms, by contrast, are unlikely to have strong capabilities and, therefore, may be more likely to innovate from entrepreneurs' initiatives and in response to specific constraints given by the context in which operate (Robson et al., 2009).

According to received wisdom, whereas the role of innovation in firms' growth in developed countries is largely documented, its impact in developing countries is still only partially understood, mainly across informal firms. Difficulties related to data availability and the measurement of innovation have limited the empirical studies on the link between innovation and firms' growth in LICs (see Wunsch-Vincent and Kraemer-Mbula, 2016).

This paper aims to fill this gap in the literature analysing data from a unique innovation survey of 501 manufacturing firms in Ghana. The survey was specifically designed to investigate the innovation activities of firms in a granular way, capturing the conventional and unstructured way firms of different level of formality, size, and absorptive capacity typically innovate. The main research questions that motivate this study are "How does innovation affect firms' growth? And are there differences between formal and informal firms?". Our results show that innovation increases labour productivity, and that technological innovations have a greater contribution than non-technological innovations. The influence of technological innovations on productivity tends to be greater for formal firms, but informal firms get as much out of non-technological innovations as formal firms do. Our study contributes to the literature by providing empirical evidence on the different roles that innovation plays in the formal and informal sectors and on the different roles that technological and non-technological innovations play in firms' growth in LICs. We thereby supplement the conventional wisdom mostly based on qualitative research that argues that poor management practices, poor standard of operations and poor quality control are the most important constraints that result in low productivity of firms in Africa.

Because of the development level of the institutions and education system, Ghana provides a potential fertile soil for innovation in the context of developing countries making this a relevant case study. However, it also shares many of its structural characteristics with other LICs and therefore the conclusions of this study are generalizable to other low-income countries. In the past thirty years, Ghana has undertaken a series of structural reforms aimed to strengthen the role of the private sector as a pillar of economic growth. In 2010, the Industrial Policy was set within the context of Ghana's long-term strategic vision of achieving middle-income status by 2020 , through the transformation of the country into an industry-driven economy. Remarkably, the Industrial Policy acknowledged the role of innovation and put in place policies aimed to increase the overall level of science, technology, and research and development in the industry. However, despite policy reforms, 
the majority of firms are still small and embedded in the informal sector, and larger firms are constrained by finance, managerial, and technical skills.

The remainder of the paper is structured as follows. Section 2 provides the literature review while Section 3 reports the model and the estimation strategy. This is followed in Section 4 by the description of the data at hand with a focus on the nature of innovation and the formal/informal status of firms. Section 5 reports and discusses the results. Finally, Section 6 concludes.

\section{Literature review}

Until a decade ago, innovation in the private sector in LICs was the focus of only a handful of studies every year (Zanello et al., 2016). Until then, innovation was often associated with patents or ground-breaking discoveries. Those are the results of costly, risky and lengthy processes that require intense knowledge and capital investment to create something "new". The Oslo Manual has been a standard reference for surveys of innovation in advanced economies and, since its third edition, also in developing countries. Its definition of innovation as "[...] the implementation of a new or significantly improved product (good or service), or process, a new marketing method, or a new organisational method in business practices, workplace organisation or external relations" (OECD, 2005: 46) highlights two important features. First, innovation can take a multitude of forms (product innovations, process innovations, marketing innovations, and managerial/organisational innovations). Second, innovation can result from an original idea but can also emerge from the diffusion, absorption, or imitation of new methods developed elsewhere. Because of that, an innovation could simply be new to the firm and not necessarily new to the market and yet have an impact on productivity and employment.

The recognized growing role of innovation in developing countries has opened a new subfield of research at the intersection of innovation studies and development studies. The socalled inclusive innovation focuses on the impact of innovation on the people living in the lowest income groups (Chataway et al., 2013). In particular, it refers to the production or delivery of new products and services for and/or by those people that so far were largely excluded from formal markets. At the same time, the constrained ingenuity and resilience of the people living below the poverty line have been recognized as an incubator for local innovation. This focus on 'frugal innovation' (Bhatti and Ventresca, 2012) introduces further considerations to understand the sources and impact of innovation in LICs. In order to access effectively new markets, companies may need to re-think the production and delivery of goods, often re-engineering products in order to reduce the complexity and cost of production. The innovation process could involve reverse diffusion (Govindarajan and Ramamurti, 2011), when innovations are adopted first in LICs before spreading to advanced 
industrial economies, jugaad innovations (Gulati, 2010), when they are born out of lack of resources by improvisation, or user innovations, when consumers are involved in the design of a product or service (Von Hippel, 1998).

\subsection{Innovation and firms' productivity in low-income countries}

Fagerberg et al. (2010) review the literature and provide strong and ample evidence on how worldwide countries that are more active in innovation have higher productivity and income than the less-innovative ones. Many scholars have argued that in developed economies the growth of firms depends on their ability to learn about their environment, linking their strategies to the changing environment (Geroski, 1989; Klepper, 1996). This is even more relevant in LICs, where infrastructure is often poor, markets tend to be underdeveloped, and potential local customers have limited disposable income. In such an environment micro, small, and medium-size firms - many of them working in the informal sector - are particularly vulnerable because of the limited absorptive capacity and restricted access to financial and knowledge resources. Those firms in LICs that are able to successfully undertake innovation activities survive, and the innovating firms that are able to make the best use of the resources available have the potential to lead the market.

In recent years, an increasing number of studies have explored in great detail the role of innovation in LIC firms. Most of these studies have looked at the impact of product or process innovations on various performance outcomes. A survey of SMEs combined with indepth case studies found a positive association between innovativeness and growth in small manufacturing firms in Tanzania (Mahemba and Bruijn, 2003). More recently, Gebreeyesus (2009) investigated the role of innovation in Ethiopian SMEs and found strong evidence that innovators grow faster than non-innovators in terms of employment. Using a rich dataset of SMEs operating in Sri Lanka, De Mel et al. (2009) find an association between innovation and profits.

Overall, the evidence emerging from the literature suggests a positive impact of innovation on firms' performance measured as either profit or employment growth. However, recent studies on the role of innovation on firms' productivity found a much weaker impact.

Goedhuys et al. $(2008,2014)$ focused on the importance of various sources of productivity in developing countries. In Tanzania, they found that firm productivity is not enhanced by $\mathrm{R} \& \mathrm{D}$, nor by product or process innovation, but business environment seems to play a more relevant role. Those conclusions suggest that the relationship between $R \& D$, innovation, and productivity is weaker in developing than in developed countries. In a subsequent study in which three sectors (food processing, textiles and garment and leather products) and five countries (Brazil, Ecuador, South Africa, Tanzania, and Bangladesh) are considered, they conclude that the link between knowledge and productivity is sector- rather than country- 
specific. In the food processing sector firms that import or license machinery and equipment are more productive, whereas no such evidence emerges in other sectors.

Especially in the context of developing countries, it is useful to differentiate between technological and non-technological innovations (often defined as the introduction of new organisational methods or new marketing methods). Although these are highly interconnected (the commercialisation of product innovations often requires new marketing methods, and new production techniques need to be supported by changes in the organisation), the factors that drive the different types of innovation are likely to be different. A decade ago, Hausman (2005) highlighted how much of the existing research had examined product and process innovations and neglected non-technological innovation, such as new management practices. Since then, management and managerial skills have received increased attention as a factor explaining differences in firms' performance in developing countries with evidence spanning various geographical areas (Bloom et al., 2013; Drexler et al., 2014; Karlan and Valdivia, 2011; Mano et al., 2012). Moreover, there is some qualitative and narrative evidence of the benefit of market innovations, mainly for firms in the informal sector (Hall et al., 2012; Ramani et al., 2012).

\subsection{Informality, innovation, and firms' productivity}

Exploring the different ways in which formal and informal firms innovate and the impact this has on their growth is critical given the size of the informal sector in developing countries. In addition, there is increasing evidence that the cure for informality is economic growth, as reported in La Porta and Shleifer (2014), and that therefore innovation could play a key role in such a transformation. Although we have a fair knowledge of the characteristics of the informal sector, there is not a single widely-accepted definition of informal firms. As reviewed in Benjamin and Mbaye (2014), scholars have used different criteria based on firm size, registration status, employer social security contributions, legal form of organization, and character (sincerity) of financial accounts. However, a consensus has emerged on the fact that there are degrees of formality and informality along a continuum rather than mutually distinct sectors (Trebilcock, 2005). Therefore, using a single indicator is likely to capture only partially the formal character of the firm. Using various indicators to capture the informal sector, La Porta and Shleifer (2008) found that it accounts for 30-40 per cent of total economic activity in the poorest countries, and an even higher share of employment.

Limited empirical evidence is available specifically on the role of innovation and firms' growth in the informal sector of developing countries (Agyapong et al., 2017; De Mel et al., 2009; Gebreeyesus, 2009; Mendi and Mudida, 2017; Konté and Ndong, 2012; WunschVincent and Kraemer-Mbula, 2016). For example, Agyapong et al. (2017) established a positive relationship between the various types of innovation and performance in small and 
medium enterprises in Ghana. Mendi and Mudida (2017) instead analysis data from informal firms in Kenya and found that past informality status negatively affect technological innovativeness. A few studies explore the determinants of innovation adoption, including firms' characteristics, such as size and the entrepreneur's level of education. Firm size, which captures the scale of operations and has been recognized as one of the defining characteristics of informal establishments, has been identified as a barrier to innovation in various studies (De Mel et al., 2009; Gebreeyesus, 2009; Robson et al., 2009). The entrepreneurs' level of education is regarded as an important, although not a sufficient, condition for innovation. Bradley et al. (2012) advocate that capital is not a "silver bullet", and education and human capital are the major constraints of innovation in Kenyan small firms. The lack of resources in the education system in many LICs makes the non-formal training the main source for learning, together with 'learning by doing' (Oyelaran-Oyeyinka and Lal, 2006).

Although ingenuity has been considered as an engine of innovation activities for informal businesses (Prahalad, 2012), most of the literature has tended to look at observable indicators (e.g. firm size, age, education of workers and entrepreneur) as determinants of innovation. In most cases data constraints have prevented the inclusion of soft skills - such as entrepreneurship and management skills - which may be equally important in the adoption and impact of innovation. An exception is the work of De Mel et al. (2009), who use a range of indicators to provide evidence that the success of informal businesses in Sri Lanka is determined not only by the skills but also the acumen of entrepreneurs. Such findings reinforce the evidence that the entrepreneur's role is more evident in small enterprises in every strategic aspect, including innovation activities (Donckels and Fröhlich, 1991).

\section{The innovation model: Econometric specification and estimation}

A recent literature review highlighted how most of the innovations in LICs have an adaptive or incremental nature, and, therefore, innovations in such settings are unlikely to leapfrog or redefine value creation processes (Zanello et al., 2016). In fact, given the limited financial and knowledge resources and absorptive capacity of firms in LICs R\&D-based innovations are uncommon. The vast majority of innovation activities derive from the adoption (and adaptation) of innovations through the so-called "technological capability", the firms' ability to employ existing technologies and knowledge in order to adopt, adapt, and change existing technologies (Fransman, 1985; Lall, 1992). Therefore, in developing countries innovation is a phenomenon that involves institutional and environmental factors as much as personal and entrepreneurial characteristics. Firm owners' entrepreneurial acumen is as critical as firms' characteristics for innovation adoption. Empirical evidence on this is limited but notably De Mel et al. (2009) control for both entrepreneurs' and firms' characteristics in the adoption of innovations. To suit these conditions, we had to take into account the lack of formal R\&D 
activities $^{1}$ and the role of firm owners' entrepreneurial acumen in adopting innovations. We therefore decided to apply a structural model that recognizes the endogeneity of innovation, i.e. that a firm innovates based on certain characteristic of the entrepreneur and the firm, and the role of innovation activity as a determinant of productivity.

The model, therefore, includes two equations. Let $\boldsymbol{i}=\mathbf{1}, \ldots, \boldsymbol{N}$ index the firm. The first equation captures the knowledge production function

$$
I_{i}^{*}=z_{i}^{\prime} \beta+\varepsilon_{i}
$$

where $\boldsymbol{I}_{\boldsymbol{i}}^{*}$ as an unobservable latent variable, and where $\boldsymbol{z}_{\boldsymbol{i}}$ is a vector of determinants of innovation effort, including the firm owner's entrepreneurial acumen, $\boldsymbol{\beta}$ is a vector of parameters of interest, and $\boldsymbol{\varepsilon}_{\boldsymbol{i}}$ is an error term. We use a probit model to estimate (1), i.e.

$$
I_{i}=\left\{\begin{array}{c}
1 \text { if } I_{i}^{*}>0 \\
\text { otherwise }
\end{array}\right.
$$

where $\boldsymbol{I}_{\boldsymbol{i}}$ is the observed binary variable equal to 1 if a firm undertook any innovation activity in the past three years and $\boldsymbol{I}_{\boldsymbol{i}}^{*}$ is the respective latent variable.

In the second step, we estimate a productivity equation

$$
y_{i}=w_{i}^{\prime} \alpha_{1}+I_{i}^{*} \alpha_{2}+v_{i}
$$

where $\boldsymbol{y}_{\boldsymbol{i}}$ is labour productivity (log of total turnover (output) per worker), $\boldsymbol{w}_{\boldsymbol{i}}$ is a vector of determinants of productivity and $\boldsymbol{v}_{\boldsymbol{i}}$ is an error term. This measure of labour productivity is widely used in innovation studies to capture firm's productivity (Fagerberg et al., 2010). The rationale is that adoption of innovation can make workers more productive. In our estimation, we take care of the endogeneity of $\boldsymbol{I}_{\boldsymbol{i}}$ by using in the estimation of (3) the predicted values from the knowledge production function equation as instruments using a two-stage least squares (2SLS) regression approach and correcting the standard errors accordingly.

In order to test our hypotheses, we expand the basic model in two directions to capture the different nature of innovations and the formal character of firms. First, we decompose the innovation activity $\left(\boldsymbol{I}_{\boldsymbol{i}}\right)$ into technological $\left(\boldsymbol{T}_{\boldsymbol{i}}\right)$ and non-technological $\left(\boldsymbol{L}_{\boldsymbol{i}}\right)$ innovation. Technological innovation includes product and process innovations, while non-technological innovation includes marketing and management innovations. The first step of the estimation is expanded to include two knowledge production functions

$$
\begin{aligned}
& T_{i}^{*}=z_{i 1}^{\prime} \beta_{1}+\varepsilon_{1 i} \\
& L_{i}^{*}=z_{i 2}^{\prime} \beta_{2}+\varepsilon_{2 i}
\end{aligned}
$$

\footnotetext{
${ }^{1}$ In our sample less than 6 per cent of the firms developed innovation through a formal R\&D department.
} 
where the starred dependent variables are latent variables and $\varepsilon_{\mathbf{1 i}}$ and $\boldsymbol{\varepsilon}_{\mathbf{2 i}}$ follow a bivariate normal distribution. We jointly estimate model (4a) and (4b) with a bivariate probit

$$
\begin{gathered}
T_{i}=\left\{\begin{array}{c}
1 \text { if } T_{i}^{*}>0 \\
0 \text { otherwise }
\end{array}\right. \\
L_{i}=\left\{\begin{array}{c}
1 \text { if } L_{i}^{*}>0 \\
0 \text { otherwise }
\end{array}\right.
\end{gathered}
$$

where $\boldsymbol{T}_{\boldsymbol{i}}$ and $\boldsymbol{L}_{\boldsymbol{i}}$ are observed binary variables equal to 1 if a firm undertook any technological, respectively non-technological, innovation activity in the past three years. The predicted values from (5a) and (5b) are then separately included as instruments in the productivity equation

$$
y_{i}=w_{i}^{\prime} \gamma_{0}+T_{i}^{*} \gamma_{1}+L_{i}^{*} \gamma_{2}+v_{i}
$$

Secondly, in order to capture the effect of innovation activities on the degree of formality of the firms, we estimate (3) and (6) interacting the two variables

$$
\begin{gathered}
y_{i}=w_{i}^{\prime} \alpha_{1}+I_{i}^{*} \alpha_{2}+N_{i} \alpha_{3}+\left(I_{i}^{*} \times N_{i}\right) \alpha_{4}+v_{i} \\
y_{i}=w_{i}^{\prime} \gamma_{0}+T_{i}^{*} \gamma_{1}+L_{i}^{*} \gamma_{2}+N_{i} \gamma_{3}+\left(T_{i}^{*} \times N_{i}\right) \gamma_{4}+\left(L_{i}^{*} \times N_{i}\right) \gamma_{5}+v_{i}
\end{gathered}
$$

where $\boldsymbol{N}_{\boldsymbol{i}}$ represents the degree of formality of a firm and $\boldsymbol{I}_{\boldsymbol{i}}^{*}, \boldsymbol{T}_{\boldsymbol{i}}^{*}$, and $\boldsymbol{L}_{\boldsymbol{i}}^{*}$ are respectively the latent variables from models (2), (5a), and (5b). ${ }^{2}$

In the estimation we rely on exclusion restrictions to identify the parameters of the innovation equation from those of the productivity equation, i.e. at least one significant explanatory variable in the knowledge production function that does not appear in the productivity equation. This variable should affect innovation, but affect productivity only through innovation. From an extensive qualitative research based on 32 in-depth interviews in 10 formal and informal firms preceding the survey emerged that access to credit was one of the main constraints to innovation. In fact, at the time of the survey the current loan interest rate $(\sim 20 \%)$ was unaffordable for most of the firms. We therefore used access to subsidised loans as exclusion restriction in our analysis, being confident that the impact of credit would affect productivity through investment in innovation.

In addition to the exclusion restrictions we also need to consider that productivity and innovation are both endogenous. More productive firms may have higher profits and more opportunities for knowledge exchange with other firms, which may result in greater innovation activities. At the same time, innovation is a driver of productivity. In the original CDM model innovation is instrumented in the productivity equation with the R\&D expenses (Crepon et al., 1998). We use instead a measure of entrepreneurship. Entrepreneurship is

\footnotetext{
${ }^{2}$ To simplify notation, we use the same notation for the error term in equations (3), (6), (7) and (8).
} 
likely to affect productivity through the implementation of innovations, both technical and non-technical.

\section{Sample and descriptive statistics}

\subsection{Data collection and sampling frame}

For this study we conducted with the support of the Science and Technology Policy Research Institute (STEPRI) an innovation survey of 501 manufacturing firms in Ghana. The data include detailed information on innovation activities undertaken by the firms during the three-year period 2010-2013. We recognised that the development and adoption of innovations follow not a static process but one that spans a certain period of time. Although the dataset is cross-sectional in nature, we recorded some data retrospectively (such as turnover) both for 2010 and 2013, allowing us to have a partial view of the dynamics and behaviour of firms during the three years under review. Considering cultural and capability factors in the sampled business community, especially in the informal sector, a one-hour face-to-face interview method was adopted for data collection.

Ten enumerators were recruited and trained specifically for data collection. The enumerators were selected amongst STEPRI staff or were derived from previous experience of data collection in other projects coordinated by STEPRI. In designing the enumerator team we made sure enumerators were able to speak local languages. During a three-day training the facilitators reviewed the questionnaire with the enumerators, offering a platform for the enumerators to interact with facilitators to allow for a possible review of the questionnaire. The enumerators were also taken through the use of the Personal Digital Assistants (PDAs). In September 2013 a pilot survey was conducted to ensure that the survey design and materials would capture the data necessary to meet the survey objectives. A sample of fifty firms was chosen from the sampled firms located in the Greater Accra Region, and each enumerator surveyed five firms, with a mix of formal and informal firms.

The data collection spanned a period of 7 weeks, from November 2013 and January 2014. During this period, survey managers visited several locations (Greater Accra, Eastern region, Ashanti region, and Central region) to monitor the progress of the data collection and support the work of the enumerators. The data were downloaded from the PDAs every week and analysed for consistency checks. In a few cases, the enumerators re-visited the firms to double-check the reliability of the data. Most of those cases involved unreliable or data entry mistakes on the number of employees, turnover, or fixed asset variables. Additional details on the survey methodology can be found in Fu et al. (2014).

The data at hand include different levels of the firms' formal character, expanding the literature on innovation in developing countries, which concentrated on innovation in 
formally registered firms (Ayyagari et al., 2011). Since informal firms tend not to be recorded in official firms' databases, we used a different sampling framework in order to avoid underrepresenting the whole informal sector. We, therefore, sampled half of the sample from sources that were likely to mainly capture informal firms and the other half from sources containing mainly formal firms. For informal firms, we randomly sampled and surveyed 25 firms in each of the 10 clusters spread in five regions. The choice of clusters and regions was determined so as to have a sector and geographical representation of the Ghanaian informal economy. Clusters were engaged in food production and processing (Oil Palm processors, Mushroom production, Shea butter production), garment and textile, handicraft producers, automotive industry and metal working, sawmill, metal working, wood workers. Five clusters were selected in Greater Accra, two in Ashanti region, and one in Central, Eastern, and Northern region respectively.

The population of firms from which we drew the sample of formal firms was compiled merging difference data sources ${ }^{3}$. The sample was then randomly selected with three levels of stratification: industrial sector, firm size, and regional location. A third of the firms originally sampled needed to be replaced. Most of those could not be located by the enumerators (24 per cent), others had closed down (8 per cent), and a few firms were not willing to participate in the survey (1 percent). Some firms are located in part of cities which do not have street names and tracking down their exact location can be a challenge. This is the case for most small and informal businesses. During the development, firms may also change location and name, or sometime switch to a different business. The replacement firms were randomly selected between the firms working in the same sector and region, and with the same size as the missing firms.

The data collected cover only manufacturing firms. Half of the firms in the sample are equally distributed in the food processing and wearing and textile sector. Fifteen per cent are active in the manufacture of furniture and metal products, and ten per cent work in wood and the manufacturing of wooden products. The remaining fifteen per cent are active in a multitude of sectors, from manufactured paper products and rubber and plastic products to the manufacture of leather or chemical products.

\subsection{Descriptive statistics}

Descriptive statistics of the firms in the sample are reported in Table 1. From our sample we see how innovation is a widespread phenomenon in the private sector in Ghana, where between 2010 and 2013 most of the firms (78 per cent) were active in some innovation

\footnotetext{
${ }^{3}$ Specifically we used the latest available National Industrial Census (2003) by Ghana Statistical Service, Micro, Small and Medium Enterprises database from Ministry of Trade and Industry, Dun \& Bradstreet database of Ghanaian firms, and the list of members of the Association of Ghana Industries (AGI).
} 
activity. When we break down the nature of innovations, we observe that most of the firms (70 per cent) are involved in some technological innovation, which include process or product innovations. This may reflect the fact that often firms in LICs work far from the technological frontier, and improvements are relatively easy or affordable to implement. Non-technological innovations, including management and marketing innovations, were implemented by 40 per cent of the firms. The vast majority of innovations introduced by the firms have an imitative and incremental nature, rather than being innovations that leapfrog or redefine value creation processes. Innovations that were born from a technology that was originally developed by others and licensed to the firm (with or without adaptation or modification) or developed in a formal R\&D department within the company by scientists and engineers, amounted to respectively six and two per cent.

Firms have been active on average for almost 16 years and employed 23 employees between 2010 and 2013. However, the distribution of the number of employees is heavily rightskewed with 73 per cent of the firms employing less than 9 workers (micro firms), 17 per cent with 10 to 29 employees (small firms), and the remaining 10 per cent is equally distributed between medium (30-99 employees) and large firms, with more than 100 employees. On average, firms have seven employees with a specialisation or university degree.

Most of the firms (63 per cent) are part of a cluster and tend to predominantly work in local markets (69 per cent). Access to subsidised loans is available for only five per cent of the firms in the sample. Finally, half of the firms sampled are located in the capital, Accra, or in Tema, a nearby industrial area with an active harbour on the Gulf of Guinea.

We capture entrepreneurship using a principal component analysis (PCA) on a series of questions that aim to capture the skills and attitude of the entrepreneurs. Those are more common in the entrepreneurial psychology literature and go beyond the entrepreneur's level of education. A similar set of questions were used by De Mel et al. (2009) in a study of Sri Lankan firms. The variables included in the PCA are listed in Table 2 and include the degree of optimism, pro-active attitude, curiosity, and tenacity. All these factors may influence the diffusion and creation of innovation. From the PCA we identified one component (eigenvalue $=3.43$ ) that captures the level of entrepreneurship with individuals that are ingenuous, proactive, methodical, and optimistic.

\subsection{The formal character of firms in the sample}


We do recognize that there is not a standard definition of formal and informal firms (Benjamin and Mbaye, 2012; Konté and Ndong, 2012) ${ }^{4}$. We, therefore, collected a selfreported formal character of the firm asking the respondents "How do you define the nature of the firm?" and providing a spectrum of options that included different degrees of formality (informal, semi-informal, semi-formal, formal), in line with the idea that formality follows a continuum (Trebilcock, 2005). Moreover, during the survey administration, the local enumerators were trained to cross-check this specific information based on the visit of a firm's premises and the observation of its activity. For this study we merged informal and semi-informal firms in one group ('informal firms') and formal with semi-formal ('formal firms') in another group. In our sample most of the firms (64 per cent) are active predominantly in the informal sector, a figure in line with other estimations of the informal establishments in Ghana and Sub-Saharan Africa (Institute of Statistical Social and Economic Research, 2013; Schneider et al., 2011).

Formal and informal firms differ in most dimensions. Informal firms are significantly less innovative than formal firms, both in technological and non-technological innovation activities. Informal firms also tend to have lower productivity and poorer entrepreneurial skills than formal firms confirming the characterization of informal firms reported in La Porta and Shleifer (2014). Informal firms are on average younger than formal firms (13 years old as opposed to 19 years old) and smaller in size, with on average only five employees compared to an average work force of 55 workers in formal firms. Despite the difference in size, the Ghana Statistical Service estimated that 48 per cent of the population in working age (16-64 years old) is employed in informal establishments (GSS, 2008). Absorptive capacity is also greater in formal firms, with on average 19 employees with a specialization degree compared to less than one employee for the informal firms. Formal and informal firms also tend to be predominantly active in different markets, with half of the formal firms active in the national or international markets and three quarters of informal firms in the local market.

Eight out of ten informal firms tend to work as part of a cluster, opposed to half of the formal firms. Clusters provide financial support, access to tools, bargaining power, and access to larger markets. The relevance of clusters also hinges on the fact that by nature they provide information that is context- and sector-specific to their members. Finally, only 14 formal firms and nine informal firms received government subsidised loans during 2010 - 2013, accounting for a mere four per cent of the total sample.

\section{Discussion of results}

\footnotetext{
${ }^{4}$ The World Bank in its Entreprise Surveys defines informal firms as firms that are not formally registered when they start operations. Konté and Ndong (2012) define informal firms as "all the production units with no statistical number and/or no formal, written accounting".
} 


\subsection{Innovation activities in Ghana}

Table 3 reports the results from the first stage of the innovation model. The determinants of innovation, technological innovation and non-technological innovation are respectively reported in Column I, II, and III. The significance of the correlation coefficient $(\boldsymbol{\rho})$ in every model suggests a significant correlation between the error terms across the two equations (the innovation and productivity equations) and therefore the efficiency of estimating them simultaneously.

Results show that formal firms are more likely to innovate than informal firms, yet when we distinguish technological and non-technological innovations, we find a significant difference only for technological innovations. This result highlights how even informal firms are equally able to adopt management and marketing innovations, which by nature are more likely to be affordable and determined by the entrepreneur's capacity. In fact, entrepreneurship is a critical factor fostering innovation activities across all the specifications in our model. This reinforces the view that innovation adoption and creation in developing countries is still greatly influenced by the acumen and skills of entrepreneurs, to an extent that we do not find in developed countries, where much of the innovation is driven by $R \& D$ activities. In less structured establishments, innovation is driven by people with characteristics that make them overcome the constraints distinctive of LICs. Entrepreneurial skills and attitude, including marked curiosity and inclination to personal relationships, are important factors in the diffusion and adoption of innovations (Bruhn et al., 2010; De Mel et al., 2009).

Consistent with previous studies of firms in Ethiopia and Ghana (Gebreeyesus, 2009; Robson et al., 2009), more mature firms are more likely to engage in innovation activities. Firms located in the conurbation area, which comprises Accra and Tema (Greater Accra region), are also associated with innovation activities, particularly non- technological innovations. Large towns provide entrepreneurs the opportunities for personal interactions, and exchange of information increases the likelihood that the entrepreneurs would be exposed to new ideas (Robson et al., 2009). Moreover, being part of a cluster is positively associated with greater innovation activities, particularly technological innovations. This results support previous findings, both from Ghana (McDade and Malecki, 1997) and other LICs (Gebreeyesus and Mohnen, 2013; Murphy, 2007).

Other results are also in line with the previous literature. A larger number of skilled employees are associated with innovation activities, and the correlation is significant for both technological and non-technological innovations. This supports the Bradley et al. (2012) study of Kenyan firms in which education and human capital were the main constraints to innovation. Competition seems to be a driver of innovation as well in the Ghanaian firms, pushing firms that work in competitive markets to innovate in order to remain in business. Market competition can nurture innovation capabilities, self-selecting firms that are able to thrive (Kumar and Saqib, 1996). Finally, access to subsidised loans is correlated as well with innovation activities. This reinforces our a priori expectation that access to credit is one of the main constraints for innovation. 


\subsection{Informality, innovation, and productivity}

Labour productivity greatly varies across the different levels of formality (Figure 1). At the lower end, informal and formal firms have a similar distribution. However, at the upper end of the spectrum, we only find formal firms that have the highest labour productivity in the sample. Such a representation is in line with previous studies of large firms that highlighted differences in productivity levels between formal and informal firms (La Porta and Shleifer, 2014). It also shows that if we exclude some highly productive formal firms, the difference between informal and formal firms is not significant at the lower end of the distribution.

The estimates of the second stages of the innovation model are reported in Table 4. For each model, that is total innovation and its two components (tech-innovation and nontechnological innovation) separately, we report two specifications with (B) and without (A) an interaction term between the innovation and the formal nature of the firm. Consistent with the mainstream literature on the role of innovation in emerging and developed countries (Fagerberg et al., 2010) and evidence from studies in LICs (Bloom et al., 2013; Gebreeyesus, 2009), the models predict a positive relationship between innovation and firms' productivity. The econometric models support the conventional wisdom that more innovative firms experience greater productivity (Model I). For example, firms increasing innovation activities from the median to the third quartile are associated with an increase in labour productivity by 11.7 per cent. However, it also shows how technological innovations have a greater impact on productivity than non-technology-based innovations (Models II and III). Adoption of technological and non-technology based innovations are respectively associated to a 14 and 7 per cent increase in labour productivity (assuming an increase in innovation activities from the median to the third quartile). In line with a growing literature on the relevance of management and managerial skills in firms in LICs (Bartz et al., 2016; Bloom et al., 2013; Mano et al., 2012), these findings suggest that the low efficiency of firms in Ghana is partially due to poor management practices, from establishing standard procedures for operations and implementing quality control to efficiently manage the inventory and human resources.

Informality is a widespread phenomenon in LICs, and a better understanding of the role of innovation in informal firms is critical for the support of economic activities that employ the vast majority of people in the non-agricultural sector. Formal firms tend to benefit more from innovation (Model I), in particular technological innovations (Model II). While informal firms tend to be characterized by modest absorptive capacity and limited resources, which may prevent them from adopting technological innovations, the role of non-technological innovation on firms' productivity is similar in formal and informal firms. 
The finding that innovation plays a crucial role for the productivity of formal and informal establishments may suggest that firms use innovation to survive. Market conditions, lack of financial resources and skills, and limited support from the government may provide a Darwinian environment in which only firms that are able to innovate, from delivering new product or services to targeting market niches, survive.

Finally, across the various specifications we found a consistent pattern that smaller firms, those located in the Greater Accra region, and those with a higher number of specialised employees and active in a national and international markets, tend to be more productive. Such results fit within the general literature providing evidence of the importance of the location for the development of firms (Robson et al., 2009). Firms nearby the capital have access to better infrastructure, larger pool of skilled labour market, and market opportunities. Specialised labour force has also been found to be one of the contributing factors of firms' labour productivity (Blundell et al., 1999).

Our results show a more relevant role of innovation on firms' productivity than the recent findings from the work of Goedhuys et al. (2008, 2014), who found that supportive business environments have a greater influence on firms' performance than innovation activities. Three differences between their studies and ours can explain the dissimilar results. First, there might be some difference because of the industry composition of the samples in the two studies, although food and garments represent half of our sample. Secondly, we have corrected for the endogeneity of innovation, something Goedhuys et al. $(2008,2014)$ have not done. Given the measurement errors inherent in the technological indicators, not instrumenting innovation may lead to an attenuation bias. But most importantly, our setting focuses only on firms located in one country and, therefore, potential cross-country differences in business environments are not captured, only cross-industry differences.

\subsection{Policy considerations}

Our results show that innovation is the most important determinant of labour productivity, for both formal and informal firms. Technological innovation has a greater contribution to productivity than non-technological innovation. Innovation tends to be adopted and developed more when loans have low interest rates, when competition is higher in the markets, when more human capital and entrepreneurship are available, and when firms are part of a cluster. Data also show that technological innovation is more frequent in formal than in informal firms. As to non-technological innovation, its diffusion is equally spread in formal and informal firms.

Based on these pieces of evidence, managerial and government policies can be developed to support and enhance the innovation activities of formal and informal firms. First, innovation can be stimulated by government policies that aim at supporting firms financially, as financial 
constraints show up as one of the major impediments to innovation (Kimura, 2011; Kugler, 2006). Such measures would benefit to a larger extent small and informal firms, for which the availability of cash flow is often a constraint in their activities (Nichter and Goldmark, 2009). Secondly, policies should be designed and implemented to provide platforms where potential employees can acquire and develop skills and firms assimilate technological progress and contribute to it. Finally, macro-economic policies and legislations should ensure a competitive environment, avoiding protected monopolies. Some competition in the market provides a conducive environment to innovate in order for firms to survive and succeed (Aghion et al., 2005).

Innovation should be supported by coordinated multi-sector policy actions that look at firms' needs (Borrás and Edquist, 2013). Targeted policy actions should also support nontechnological innovation, such as managerial innovation. Policies aimed at developing and supporting clusters and networks can provide fertile spaces for knowledge spillovers and information exchange. Moreover, policies should recognise the importance of promoting an entrepreneurial attitude, i.e. a willingness to take risks and a determination to succeed. This can be developed by creating safety nets, and nurturing the recognition of 'failures' as learning opportunities along the path to success.

\section{Conclusion}

Low-income countries rely on the transfer of technologies and knowledge from more advanced countries to increase the local wealth and welfare, reduce internal inequalities, and ultimately accelerate the process of catching up. The current developmental state of most LICs suggests that the diffusion to and adoption of major technologies in LICs are likely to be faster than what we witnessed with the diffusion of major innovations, such as the steam engine, which took hundred years to be adopted in China. Economies nowadays are intrinsically more interconnected and lower-tech innovations have the potential to be adopted by LICs, favoured by trade and collaborations between LICs and emerging countries. The rationale is that the knowledge transferred to LICs is likely to be more appropriate since it comes from countries with not too dissimilar factor endowments. The absorptive capacity of an LIC recipient may be more prone to receiving a similar level of technology. We are witnessing an initial process in which manufacturing industries will eventually be relocated to places - such as African countries - where labour is cheaper than in current manufacturing countries, where worldwide low-tech goods have been assembled and produced for decades. Nowadays the diffusion of information and communication technologies holds the potential to promote the diffusion of information in places that until recently were disconnected and remote, and the increased capability with which people can move and travel is a powerful vector to support absorptive capacity of LICs with the injection of knowledge and skills. 
In such a scenario, our results aim to provide a better understanding of the critical role of innovation on firms' growth in LICs. These firms have characteristics and work in an environment that is very different from that of many firms in emerging countries and most of the firms in advanced economies. The vast majority of the firms in LICs are informal; they employ a large proportion of the population but work extremely inefficiently and in a low productivity regime. Moreover, the historical, socio-economic, and political environment of LICs provides strong challenges to firms, which face acute obstacles, from knowledge to market and resource constraints. We found that in such an environment innovation is a determinant factor for firms' productivity, with greater effect in formal firms.

Policies play a critical role in accelerating the diffusion and creation of innovation and mitigating the obstacles LICs face. Findings from this research has important policy implications. Firstly, it should be more strongly emphasized among policy-makers that innovation is not the outcome of development but a means for development. Too often in LICs, in the informal economy in particular, innovations are not recognized, and innovation efforts are not properly supported. Therefore, new thinking and policies to recognize and support innovation, for example by mitigating financial and labour skills constraints, are necessary in the context of LICs for long-term growth and development. In Ghana, recognizing the important role that knowledge and innovation must play in transforming the economy and reducing poverty, the Government of Ghana has placed Science and Technology (S\&T) development high on its list of priorities (Amankwah-Amoah, 2016). This is reflected in various political and policy statements, including Vision 2020, the Growth and Poverty Reduction Strategy II, and the medium-term development plan. These policies and strategies have emphasised that the absorption and application of much more S\&T is a critical ingredient for successful growth. As with many other economies in sub-Saharan Africa, Ghana is still in the stage of 'factor-driven' growth. In the next decade, policy-makers in Ghana must address these issues in order to move from a 'factor-driven' growth into an 'innovation-driven' one.

Secondly, this study suggests that non-technological innovations also have a significant positive impact on labour productivity, although the size of its impact is smaller than that of technology-based innovations. Poor management practices, poor standard of operations, and poor quality control have been argued as important constraints for productivity growth in Africa. Therefore, government policies should also promote the diffusion and adoption of appropriate modern management practices, which may provide Africa with another engine of economic growth.

\section{Acknowledgements}


This research was supported by the ESRC/DFID Grant 'The Diffusion of Innovation in Low Income Countries' (ES/J008699/1). We would like to thank Marc Ventresca, Douglas Gollin, and Abhijeet Singh for helpful comments and suggestions. We are also grateful for comments from participants at the Development Studies Association 2014 Annual conference (London, UK), Seminar at the Oxford Department of International Development, OECD Blue Sky conference (Ghent, Belgium), and 'Informality and Development: A Conference in Honour of Elinor Ostrom' Bloomington (IN, US). 
Table 1: Sample description

\begin{tabular}{|c|c|c|c|c|c|}
\hline & Description and unit & $\begin{array}{c}\text { Mean } \\
\text { full sample }\end{array}$ & $\begin{array}{l}\text { Informal firms } \\
\quad(n=321)\end{array}$ & $\begin{array}{l}\text { Formal firms } \\
\quad(n=180)\end{array}$ & $\begin{array}{c}\text { Difference } \\
\text { (informal- } \\
\text { formal) }\end{array}$ \\
\hline \multicolumn{6}{|l|}{ Dependent variables } \\
\hline Innovation & Whether the firm implemented any innovation (dummy) & 0.78 & 0.72 & 0.89 & $-0.18 * * *$ \\
\hline Technological innovation & Whether the firm implemented a technological innovation (dummy) & 0.70 & 0.62 & 0.84 & $-0.23 * * *$ \\
\hline Non-technological innovation & Whether the firm implemented a non-tech. innovation (dummy) & 0.40 & 0.35 & 0.51 & $-0.16 * * *$ \\
\hline Labour productivity & $\log$ (Turnover [in 1,000 $\mathrm{GH} \phi]$ / Number of employees) & 0.37 & 0.18 & 0.71 & $-0.53 * * *$ \\
\hline \multicolumn{6}{|l|}{ Independent variables } \\
\hline Formal & Whether the firm is formal (dummy) & 0.36 & - & - & - \\
\hline Capital / labour & Fixed assets [in 1,000 GH $\phi$ ] / Number of employees $(\log )$ & 39.38 & 2.14 & 105.81 & $-103.70 * * *$ \\
\hline Entrepreneurship & First component of entrepreneurship (PCA) & 0.00 & -0.26 & 0.46 & $-0.71 * * *$ \\
\hline Size & Number of employees $(\log )$ & 23.14 & 5.35 & 54.88 & $-49.53 * * *$ \\
\hline Age & Age of the firm $(\log )$ & 15.82 & 13.57 & 19.83 & $-6.26 * * *$ \\
\hline Conurbation & Whether the firm is located in Accra or Tema (dummy) & 0.50 & 0.50 & 0.50 & -0.01 \\
\hline Skilled employees & Number of employees with specialization or university degree & 7.14 & 0.28 & 19.36 & $-19.08 * * *$ \\
\hline Competition & Degree of competition in the main market (from low (1) to high (5)) & 2.40 & 2.27 & 2.64 & $-0.38 * * *$ \\
\hline Local & Whether the firm predominantly marketed locally (dummy) & 0.69 & 0.77 & 0.54 & $0.23 * * *$ \\
\hline Member of cluster & Whether the firm is member of a cluster (dummy) & 0.63 & 0.81 & 0.30 & $0.51 * * *$ \\
\hline Subsidized loan & Whether the firm obtained a subsidized loan (dummy) & 0.05 & 0.03 & 0.08 & $-0.05 *$ \\
\hline
\end{tabular}

Notes: Statistics are reported for natural variables. Significance at the 10 per cent, 5 per cent and 1 per cent levels are indicated by one, two and three asterisks respectively. 
Table 2: Entrepreneurship: Principal component (eigenvectors) and variable used.

\begin{tabular}{|l|c|c|c|c|c|}
\cline { 2 - 6 } \multicolumn{1}{c|}{} & $\begin{array}{c}\text { Mean full } \\
\text { sample }\end{array}$ & $\begin{array}{c}\text { Informal firms } \\
(\mathrm{n}=321)\end{array}$ & $\begin{array}{c}\text { Formal firms } \\
\text { (n=180) }\end{array}$ & $\begin{array}{c}\text { Difference } \\
\text { (formal- } \\
\text { informal) }\end{array}$ & PCA Component 1 \\
\hline A. I plan tasks carefully & & & 4.29 & 0.14 & 0.407 \\
B. I will pursue my goal despite many failures and oppositions & 4.27 & 4.27 & 4.38 & $0.18^{*}$ & 0.447 \\
C. I am well organised and good at multi-tasking & 4.02 & 3.93 & 4.17 & $0.23^{*}$ & 0.392 \\
D. I am fully prepared to take risks & 3.94 & 3.74 & 4.29 & $0.54^{* * *}$ & 0.392 \\
E. I am always optimistic about my future & 4.24 & 4.16 & 4.39 & $0.23^{*}$ & 0.411 \\
F. A person can get rich by taking risks & 3.75 & 3.57 & 4.08 & $0.51^{* * *}$ & 0.399 \\
\hline
\end{tabular}

Notes: Responses to all questions are coded on a scale of one to five, with one indicating "strongly disagree" and five "strongly agree". 
Table 3: First stage of innovation model: Determinants of innovation (Model I) and technological and non-technological innovation (Model II and III)

\begin{tabular}{|c|c|c|c|}
\hline & $\begin{array}{c}\text { Model I: } \\
\text { (Innovation) }\end{array}$ & $\begin{array}{c}\text { Model II: } \\
\text { (Tech-innovation) }\end{array}$ & $\begin{array}{c}\text { Model III: } \\
\text { (Non-tech innovation) }\end{array}$ \\
\hline Formal firm & $\begin{array}{l}0.117 * * \\
(0.053)\end{array}$ & $\begin{array}{l}0.149 * * * \\
(0.049)\end{array}$ & $\begin{array}{c}0.007 \\
(0.047)\end{array}$ \\
\hline Entrepreneurship (PCA) & $\begin{array}{l}0.043 * * * \\
(0.012)\end{array}$ & $\begin{array}{l}0.053 * * * \\
(0.009)\end{array}$ & $\begin{array}{l}0.047 * * * \\
(0.008)\end{array}$ \\
\hline Capital/labour & $\begin{array}{l}-0.004 \\
(0.015)\end{array}$ & $\begin{array}{l}-0.001 \\
(0.012)\end{array}$ & $\begin{array}{c}0.022 \\
(0.010)\end{array}$ \\
\hline Firm size (log) & $\begin{array}{l}-0.027 \\
(0.023)\end{array}$ & $\begin{array}{c}0.001 \\
(0.021)\end{array}$ & $\begin{array}{c}0.031 \\
(0.019)\end{array}$ \\
\hline Skilled employees (log) & $\begin{array}{l}0.033 * * * \\
(0.010)\end{array}$ & $\begin{array}{l}0.024 * * \\
(0.011)\end{array}$ & $\begin{array}{l}0.022 * * \\
(0.012)\end{array}$ \\
\hline Age $(\log )$ & $\begin{array}{l}0.047 * * \\
(0.029)\end{array}$ & $\begin{array}{l}0.043 * * \\
(0.022)\end{array}$ & $\begin{array}{l}0.069 * * \\
(0.019)\end{array}$ \\
\hline Conurbation & $\begin{array}{l}0.087 * * \\
(0.041)\end{array}$ & $\begin{array}{l}0.047 * * \\
(0.038)\end{array}$ & $\begin{array}{l}0.171 * * \\
(0.033)\end{array}$ \\
\hline Local & $\begin{array}{r}0.077 * \\
(0.051)\end{array}$ & $\begin{array}{c}0.061 \\
(0.046)\end{array}$ & $\begin{array}{c}0.091 * \\
(0.042)\end{array}$ \\
\hline Competition & $\begin{array}{l}0.044 * * \\
(0.018)\end{array}$ & $\begin{array}{l}0.049 * * \\
(0.021)\end{array}$ & $\begin{array}{l}0.039 * * \\
(0.019)\end{array}$ \\
\hline Subsidized loan & $\begin{array}{l}0.221 * * \\
(0.112)\end{array}$ & $\begin{array}{l}0.216 * * \\
(0.091)\end{array}$ & $\begin{array}{l}0.265 * * \\
(0.084)\end{array}$ \\
\hline Member of cluster & $\begin{array}{r}0.065^{*} \\
(0.045)\end{array}$ & $\begin{array}{l}0.077 * * \\
(0.037)\end{array}$ & $\begin{array}{c}0.067 \\
(0.034)\end{array}$ \\
\hline Correlation $(\rho)$ & $\begin{array}{l}-0.609 * * * \\
(0.236)\end{array}$ & $\begin{array}{l}-0.628 * * \\
(0.248)\end{array}$ & $\begin{array}{l}-0.354 * \\
(0.184)\end{array}$ \\
\hline $\begin{array}{l}\text { Pseudo R-Squared } \\
\text { Wald } \chi^{2}\end{array}$ & $\begin{array}{l}0.19 \\
99.39 * * *\end{array}$ & $\begin{array}{l}0.16 \\
95.84 * * *\end{array}$ & $\begin{array}{c}0.14 \\
91.75^{* * *}\end{array}$ \\
\hline $\begin{array}{l}\text { Correctly classified } \\
\text { Ratio correct prediction }{ }^{\text {a }}\end{array}$ & $\begin{array}{c}82 \% \\
1.26\end{array}$ & $\begin{array}{l}75 \% \\
1.29\end{array}$ & $\begin{array}{l}70 \% \\
1.31\end{array}$ \\
\hline Observations & 501 & 501 & 501 \\
\hline
\end{tabular}

Notes: Marginal effects are reported. For each model (I, II, and III), are reported the estimates and statistics (R-squared, rho, prediction) of Model A (second stage in Table 4). Estimates of the first stage Model A and B are not significantly different. Significance at the 10 per cent, 5 per cent and 1 per cent levels are indicated by one, two and three asterisks respectively. Robust standard errors are in parentheses. $\rho$ refers to the correlation between the error terms in the innovation and the productivity equations (tables 3 and 4 , col A, resp.).

${ }^{a}$ The ratio of correct prediction is a measure of goodness of fit. It is computed as the sum of the fraction of zeros correctly predicted and the ones correctly predicted (McIntosh and Dorfman, 1992). The model is considered robust if the ratio is greater than one. 
Table 4: Second stage of the innovation model: Determinants of firm's productivity by innovation (Model I) and technological and non-technological innovation (Model II and III)

\begin{tabular}{|c|c|c|c|c|c|c|}
\hline & \multicolumn{2}{|c|}{$\begin{array}{c}\text { Model I: } \\
\text { (Labour productivity) }\end{array}$} & \multicolumn{2}{|c|}{$\begin{array}{c}\text { Model II: } \\
\text { (Labour productivity) }\end{array}$} & \multicolumn{2}{|c|}{$\begin{array}{c}\text { Model III: } \\
\text { (Labour productivity) }\end{array}$} \\
\hline & $\mathrm{A}$ & $\mathrm{B}$ & $\mathrm{A}$ & $\mathrm{B}$ & $\mathrm{A}$ & $\mathrm{B}$ \\
\hline Innovation & $\begin{array}{l}1.209 * * * \\
(0.293)\end{array}$ & $\begin{array}{l}1.221 * * * \\
(0.256)\end{array}$ & & & & \\
\hline Technological innovation & & & $\begin{array}{l}1.074 * * * \\
(0.327)\end{array}$ & $\begin{array}{l}1.110^{* * * *} \\
(0.308)\end{array}$ & & \\
\hline Non-technological innovation & & & & & $\begin{array}{l}0.474 * \\
(0.276)\end{array}$ & $\begin{array}{l}0.482 * \\
(0.291)\end{array}$ \\
\hline Innovation x Formal firm & & $\begin{array}{l}0.722 * * * \\
(0.249)\end{array}$ & & & & \\
\hline Technological innovation x Formal firm & & & & $\begin{array}{l}0.489 * * \\
(0.248)\end{array}$ & & \\
\hline Non-technological innovation $\mathrm{x}$ Formal firm & & & & & & $\begin{array}{l}-0.018 \\
(0.194)\end{array}$ \\
\hline Formal firm & $\begin{array}{l}0.158 \\
(0.106)\end{array}$ & $\begin{array}{l}-0.475^{*} \\
(0.247)\end{array}$ & $\begin{array}{l}0.147 \\
(0.112)\end{array}$ & $\begin{array}{l}-0.261 \\
(0.238)\end{array}$ & $\begin{array}{l}0.323 * * * \\
(0.101)\end{array}$ & $\begin{array}{l}0.330 * * * \\
(0.126)\end{array}$ \\
\hline Capital/labour & $\begin{array}{l}-0.003 \\
(0.055)\end{array}$ & $\begin{array}{l}-0.005 \\
(0.055)\end{array}$ & $\begin{array}{l}0.011 \\
(0.057)\end{array}$ & $\begin{array}{l}0.010 \\
(0.058)\end{array}$ & $\begin{array}{l}0.023 \\
(0.052)\end{array}$ & $\begin{array}{l}0.022 \\
(0.052)\end{array}$ \\
\hline Firm size $(\log )$ & $\begin{array}{l}0.498 * * * \\
(0.043)\end{array}$ & $\begin{array}{l}0.503 * * * \\
(0.044)\end{array}$ & $\begin{array}{l}0.500 * * * \\
(0.044)\end{array}$ & $\begin{array}{l}0.502 * * * \\
(0.045)\end{array}$ & $\begin{array}{l}0.492 * * * \\
(0.045)\end{array}$ & $\begin{array}{l}0.492 * * * \\
(0.045)\end{array}$ \\
\hline Skilled employees $(\log )$ & $\begin{array}{l}-0.356^{* * * *} \\
(0.062)\end{array}$ & $\begin{array}{l}-0.360 * * * \\
(0.063)\end{array}$ & $\begin{array}{l}-0.388 * * * \\
(0.062)\end{array}$ & $\begin{array}{l}-0.392 * * * \\
(0.064)\end{array}$ & $\begin{array}{l}-0.407 * * * \\
(0.063)\end{array}$ & $\begin{array}{l}-0.407 * * * \\
(0.063)\end{array}$ \\
\hline Age $(\log )$ & $\begin{array}{l}0.072 * * * \\
(0.022)\end{array}$ & $\begin{array}{l}0.062 * * * \\
(0.023)\end{array}$ & $\begin{array}{l}0.079 * * * \\
(0.023)\end{array}$ & $\begin{array}{l}0.072 * * * \\
(0.023)\end{array}$ & $\begin{array}{l}0.089 * * * \\
(0.023)\end{array}$ & $\begin{array}{l}0.089 * * * \\
(0.023)\end{array}$ \\
\hline Conurbation & $\begin{array}{l}0.353 * * * \\
(0.094)\end{array}$ & $\begin{array}{l}0.370 * * * \\
(0.097)\end{array}$ & $\begin{array}{l}0.422 * * * \\
(0.094)\end{array}$ & $\begin{array}{l}0.444 * * * \\
(0.097)\end{array}$ & $\begin{array}{l}0.385 * * * \\
(0.095)\end{array}$ & $\begin{array}{l}0.384 * * * \\
(0.095)\end{array}$ \\
\hline Local & $\begin{array}{l}-0.258 * * \\
(0.106)\end{array}$ & $\begin{array}{l}-0.301 * * * \\
(0.109)\end{array}$ & $\begin{array}{l}-0.233 * * \\
(0.105)\end{array}$ & $\begin{array}{l}-0.268^{* *} \\
(0.107)\end{array}$ & $\begin{array}{l}-0.215^{* *} \\
(0.102)\end{array}$ & $\begin{array}{l}-0.215^{* *} \\
(0.102)\end{array}$ \\
\hline Constant & $\begin{array}{l}0.087 \\
(0.299)\end{array}$ & $\begin{array}{l}0.071 \\
(0.289)\end{array}$ & $\begin{array}{l}0.275 \\
(0.298)\end{array}$ & $\begin{array}{l}0.246 \\
(0.295)\end{array}$ & $\begin{array}{l}0.815 * * * \\
(0.223)\end{array}$ & $\begin{array}{l}0.814 * * * \\
(0.224)\end{array}$ \\
\hline $\begin{array}{l}\text { R-Squared } \\
\text { Wald } \chi^{2}\end{array}$ & $\begin{array}{l}0.50 \\
60.74 * * *\end{array}$ & $\begin{array}{l}0.50 \\
54.43 * * *\end{array}$ & $\begin{array}{l}0.49 \\
58.99 * * *\end{array}$ & $\begin{array}{l}0.49 \\
52.55 * * *\end{array}$ & $\begin{array}{l}0.49 \\
57.96^{* * *}\end{array}$ & $\begin{array}{l}0.49 \\
51.42 * * *\end{array}$ \\
\hline Observations & 501 & 501 & 501 & 501 & 501 & 501 \\
\hline
\end{tabular}

Notes: Significance at the 10 per cent, 5 per cent and 1 per cent levels are indicated by one, two and three asterisks respectively. Robust standard errors are in parentheses. 
Figure 1: Distribution of labour productivity by level of formality of the firms.

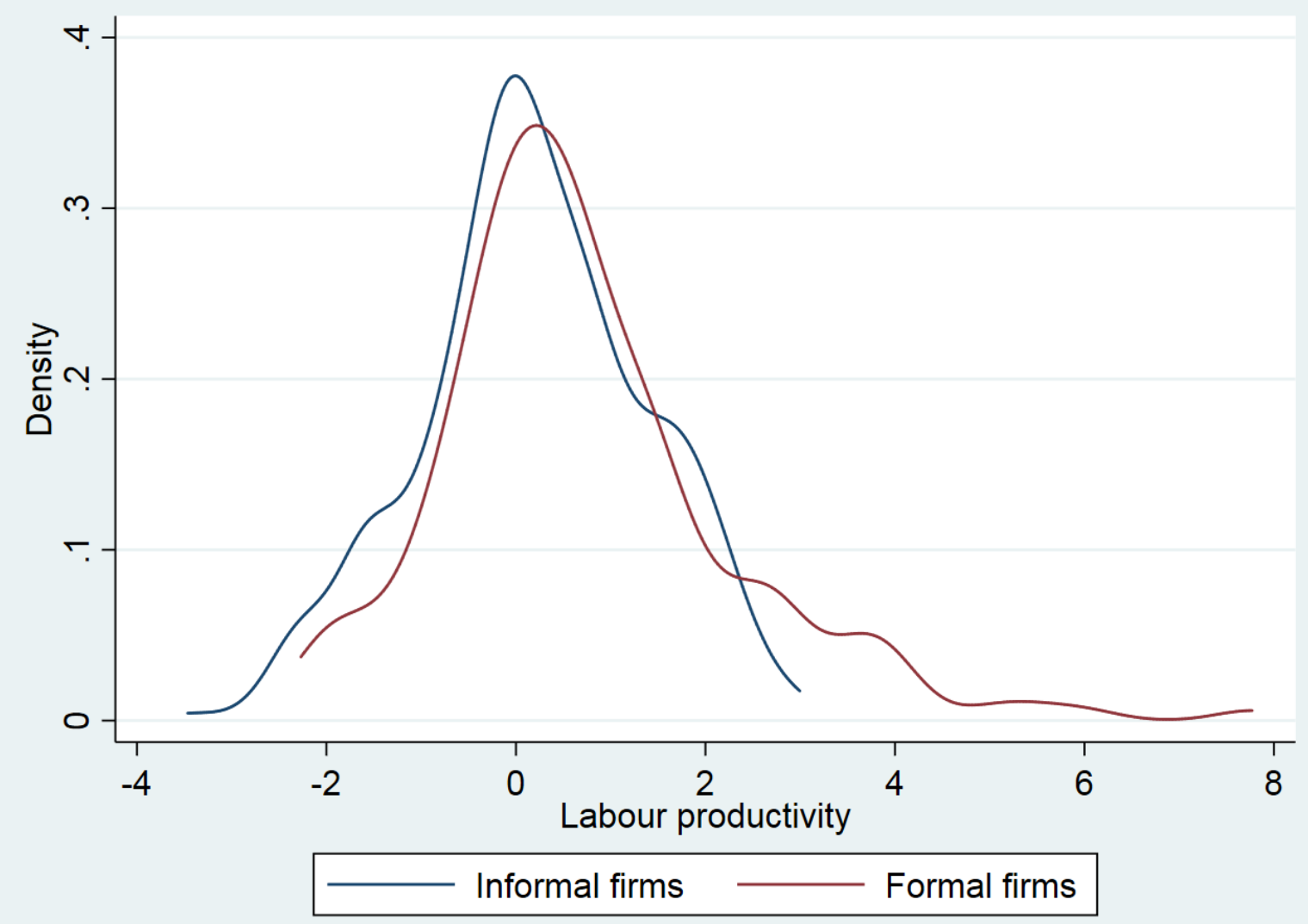




\section{Reference}

Aghion, P., Bloom, N., Blundell, R., Griffith, R., and Howitt, P. (2005). Competition and Innovation: an Inverted-U Relationship. The Quarterly Journal of Economics 120, 701-728.

Agyapong, F. O., Agyapong, A., Poku, K., and Davis, J. L. (2017). Nexus between social capital and performance of micro and small firms in an emerging economy: The mediating role of innovation. Cogent Business \& Management 4, 1309784.

Amankwah-Amoah, J. (2016). The evolution of science, technology and innovation policies: A review of the Ghanaian experience. Technological Forecasting and Social Change 110, 134-142.

Ayyagari, M., Demirguc-Kunt, A., and Maksimovic, V. (2011). Firm innovation in emerging markets: The role of finance, governance, and competition. Journal of Financial and Quantitative Analysis 46, 1545-1580.

Bartz, W., Mohnen, P., and Schweiger, H. (2016). "The role of innovation and management practices in determining firm productivity in developing economies," Working Paper 187. European Bank for Reconstruction and Development, London (UK).

Bell, M., and Pavitt, K. (1992). Accumulating technological capability in developing-countries. World Bank Economic Review, 257-281.

Benjamin, N. C., and Mbaye, A. A. (2012). The informal sector, productivity, and enforcement in West Africa: A firm-level analysis. Review of Development Economics 16, 664-680.

Benjamin, N. C., and Mbaye, A. A. (2014). "Informality, growth, and development in Africa," UNUWIDER Working Paper 2014-52. UNU-WIDER, Helsinki (Finland).

Bhatti, Y., and Ventresca, M. (2012). The emerging market for frugal innovation: Fad, fashion, or fit? Available at SSRN: http://ssrn.com/abstract $=2005983$.

Bloom, N., Eifert, B., Mahajan, A., McKenzie, D., and Roberts, J. (2013). Does Management Matter? Evidence from India. Quarterly Journal of Economics 128, 1-51.

Blundell, R., Dearden, L., Meghir, C., and Sianesi, B. (1999). Human capital investment: the returns from education and training to the individual, the firm and the economy. Fiscal studies 20, 123.

Borrás, S., and Edquist, C. (2013). The choice of innovation policy instruments. Technological Forecasting and Social Change 80, 1513-1522.

Bradley, S. W., McMullen, J. S., Artz, K., and Simiyu, E. M. (2012). Capital is not enough: Innovation in developing economies. Journal of Management Studies 49, 684-717.

Bruhn, M., Karlan, D., and Schoar, A. (2010). What capital is missing in developing countries? American Economic Review: Papers \& Proceedings 100, 629-33.

Chataway, J., Hanlin, R., and Kaplinsky, R. (2013). Inclusive innovation: An architecture for policy development. IKD Working Paper No. 65.

Chen, M., Sebstad, J., and O'Connell, L. (1999). Counting the invisible workforce: The case of homebased workers. World Development 27, 603-610.

Cohen, W. M., and Levinthal, D. A. (1989). Innovation and learning: The two faces of R\&D. The Economic Journal 99, 569-596.

Crepon, B., Duguet, E., and Mairesse, J. (1998). Research, innovation and productivity: An econometric analysis at the firm level. Economics of Innovation and New Technology 7, 115158.

Crespi, G., and Zuniga, P. (2012). Innovation and productivity: evidence from six Latin American countries. World development 40, 273-290.

De Mel, S., McKenzie, D., and Woodruff, C. (2009). "Innovative firms or innovative owners? Determinants of innovation in micro, small, and medium enterprises," World Bank Policy Research Working Paper 4934. The World Bank, Washington DC (US).

Donckels, R., and Fröhlich, E. (1991). Are family businesses really different? European experiences from STRATOS. Family Business Review 4, 149-160.

Drexler, A., Fischer, G., and Schoar, A. (2014). Keeping it simple: Financial literacy and rules of thumb. American Economic Journal: Applied Economics 6, 1-31. 
Fagerberg, J., Srholec, M., and Verspagen, B. (2010). Innovation and economic development. In "Handbook of the Economics of Innovation" (H. H. Bronwyn and N. Rosenberg, eds.), Vol. 2, pp. 833-872. North-Holland.

Fransman, M. (1985). Conceptualizing technical change in the Third-World in the 1980s: An Interpretive Survey. Journal of Development Studies 21, 572-652.

$\mathrm{Fu}, \mathrm{X}$., and Gong, Y. (2011). Indigenous and foreign innovation efforts and drivers of technological upgrading: Evidence from China. World Development 39, 1213-1225.

Fu, X., Zanello, G., Essegbey, G. O., Hou, J., and Mohnen, P. (2014). "Innovation in low income countries: A survey report." TMCD and DEGRP, Oxford (UK).

Gebreeyesus, M. (2009). Innovation and microenterprises growth in Ethiopia. In "Entrepreneurship, innovation, and economic development" (A. Szirmai, W. A. Naudé and M. Goedhuys, eds.). Oxford University Press, Oxford (UK).

Gebreeyesus, M., and Mohnen, P. (2013). Innovation Performance and Embeddedness in Networks: Evidence from the Ethiopian Footwear Cluster. World Development 41, 302-316.

Geroski, P. A. (1989). Entry, innovation and productivity growth. The Review of Economics and Statistics, 572-578.

Goedhuys, M. (2007). Learning, product innovation, and firm heterogeneity in developing countries: Evidence from Tanzania. Industrial and Corporate Change 16, 269-292.

Goedhuys, M., Janz, N., and Mohnen, P. (2008). What drives productivity in Tanzanian manufacturing firms: technology or business environment? European Journal of Development Research 20, 199-218.

Goedhuys, M., Janz, N., and Mohnen, P. (2014). Knowledge-based productivity in "low-tech" industries: Evidence from firms in developing countries. Industrial and Corporate Change 23, $1-23$.

Govindarajan, V., and Ramamurti, R. (2011). Reverse innovation, emerging markets, and global strategy. Global Strategy Journal 1, 191-205.

Grossman, G. M., and Helpman, E. (1991). "Innovation and growth in the global economy," The MIT Press, Cambridge, MA (US).

GSS (2008). "Ghana Living Standards Survey: Report of the 5th round." Ghana Statistical Service, Accra, Ghana.

Gulati, R. (2010). Management Lessons From the Edge. Academy of Management Perspectives 24, 25-27.

Hall, J., Matos, S., Sheehan, L., and Silvestre, B. (2012). Entrepreneurship and innovation at the Base of the Pyramid: A recipe for inclusive growth or social exclusion? Journal of Management Studies 49, 785-812.

Hausman, A. (2005). Innovativeness among small businesses: Theory and propositions for future research. Industrial Marketing Management 34, 773-782.

Institute of Statistical Social and Economic Research (2013). The State of Ghanaian Economy in 2012. Legon University Press, Accra, Ghana.

Jovanovic, B. (1982). Selection and the evolution of industry. Econometrica 50, 649-670.

Karlan, D., and Valdivia, M. (2011). Teaching entrepreneurship: Impact of business training on microfinance clients and institutions. Review of Economics and Statistics 93, 510-527.

Keller, W. (1996). Absorptive capacity: On the creation and acquisition of technology in development. Journal of Development Economics 49, 199-227.

Keller, W. (2004). International technology diffusion. Journal of Economic Literature 42, 752-782.

Kimura, Y. (2011). Knowledge diffusion and modernization of rural industrial clusters: A papermanufacturing village in Northern Vietnam. World Development 39, 2105-2118.

Kleinknecht, A., and Mohnen, P. A. (2002). "Innovation and firm performance: Econometric explorations of survey data," Palgrave, Basingstoke (UK).

Klepper, S. (1996). Entry, exit, growth, and innovation over the product life cycle. American Economic Review 86, 562-583. 
Konté, A., and Ndong, M. (2012). "The informal ICT sector and innovation processes in Senegal," UNU-MERIT Working Paper. UNU-MERIT, Maastricht (The Netherlands)

Kugler, M. (2006). Spillovers from foreign direct investment: Within or between industries? Journal of Development Economics 80, 444-477.

Kumar, N., and Saqib, M. (1996). Firm size, opportunities for adaptation and in-house R\&D activity in developing countries: The case of Indian manufacturing. Research Policy 25, 713-722.

La Porta, R., and Shleifer, A. (2008). "The unofficial economy and economic development," Brookings Papers on Economic Activity 39. The Brookings Institution, Washington DC, USA.

La Porta, R., and Shleifer, A. (2014). Informality and development. Journal of Economic Perspectives 28, 109-26.

Lall, S. (1992). Technological capabilities and industrialization. World Development 20, 165-186.

Lundvall, B.-Å., Joseph, K. J., Chaminade, C., and Vang, J. (2010). "Handbook of Innovation Systems and Developing Countries: Building Domestic Capabilities in a Global Setting," Edward Elgar Publishing, Cheltenham, UK.

Mahemba, C. M., and Bruijn, E. J. (2003). Innovation activities by small and medium-sized manufacturing enterprises in Tanzania. Creativity and Innovation Management 12, 162-173.

Mano, Y., Iddrisu, A., Yoshino, Y., and Sonobe, T. (2012). How can micro and small enterprises in SubSaharan Africa become more productive? The impacts of experimental basic managerial training. World Development 40, 458-468.

McDade, B. E., and Malecki, E. J. (1997). Entrepreneurial networking: Industrial estates in Ghana. Tijdschrift Voor Economische En Sociale Geografie 88, 262-272.

McIntosh, C. S., and Dorfman, J. H. (1992). Qualitative forecast evaluation: A comparison of two performance measures. American Journal of Agricultural Economics 74, 209-214.

Mendi, P., and Mudida, R. (2017). The effect on innovation of beginning informal: Empirical evidence from Kenya. Technological Forecasting and Social Change. In press.

Murphy, J. T. (2007). The challenge of upgrading in African industries: Socio-spatial factors and the urban environment in Mwanza, Tanzania. World Development 35, 1754-1778.

Nichter, S., and Goldmark, L. (2009). Small Firm Growth in Developing Countries. World Development 37, 1453-1464.

OECD (2005). "Oslo Manual: Guidelines for collecting and interpreting innovation data," 3rd/Ed. OECD Publishing, Paris.

Oyelaran-Oyeyinka, B., Laditan, G. O. A., and Esubiyi, A. O. (1996). Industrial innovation in SubSaharan Africa: The manufacturing sector in Nigeria. Research Policy 25, 1081-1096.

Oyelaran-Oyeyinka, B., and Lal, K. (2006). Learning new technologies by small and medium enterprises in developing countries. Technovation 26, 220-231.

Prahalad, C. K. (2012). Bottom of the Pyramid as a source of breakthrough innovations. Journal of Product Innovation Management 29, 6-12.

Ramani, S. V., Sadre Ghazi, S., and Duysters, G. (2012). On the diffusion of toilets as bottom of the pyramid innovation: Lessons from sanitation entrepreneurs. Technological Forecasting and Social Change 79, 676-687.

Robson, P. J. A., Haugh, H. M., and Obeng, B. A. (2009). Entrepreneurship and innovation in Ghana: Enterprising Africa. Small Business Economics 32, 331-350.

Schneider, F., Buehn, A., and Montenegro, C. E. (2011). Shadow economies all over the world: New estimates for 162 countries from 1999 to 2007. International Economic Journal 24, 443-461.

Trebilcock, A. (2005). "Decent work and the informal economy," UNU-WIDER Working Paper 200504. UNU-WIDER, Helsinki (Finland).

Von Hippel, E. (1998). "The sources of innovation," Oxford University Press, Oxford (UK).

Wang, H. C. (2010). Discovering steam power in China, 1840s-1860s. Technology and Culture 51, 3154. 
Wunsch-Vincent, S., and Kraemer-Mbula, E. (2016). "The Informal Economy in Developing Nations: Hidden Engine of Innovation? New economic insights and policies," Cambridge University Press, Cambridge (UK).

Zanello, G., Fu, X., Mohnen, P., and Ventresca, M. (2016). The creation and diffusion of innovation in developing countries: A systematic literature review. Journal of Economic Surveys 30, 884912. 